\title{
Sustainable food production with greenhouse technologies
}

\author{
Gonda, Gy. ${ }^{1}$, Mubarak Y. M. Al-AliNoor ${ }^{1}$, Fekete-Farkas, M. ${ }^{2}$ \& Helyes, L. ${ }^{3}$

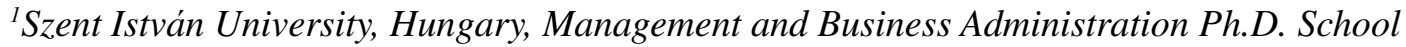 \\ H-2103 Gödöllö, Páter K. u. 1. Hungary \\ ${ }^{2}$ Szent István University, Hungary, Faculty of Social Sciences and Economics \\ H-2103 Gödöllö, Páter K. u. 1. Hungary \\ e-mail: Farkasne.Fekete.Maria@gtk.szie.hu \\ ${ }^{3}$ Szent István University, Hungary, Faculty of Agricultural and Environmental Sciences \\ H-2103 Gödöllö, Páter K. u. 1. Hungary,e-mail: Helyes.Lajos@mkk.szie.hu
}

Summary: The greenhouse fruit and vegetable production is one important area which supports sustainability. To achieve sustainable economy and growth, the given natural resources have to be used in a smarter, renewable way in order to avoid depleting them. New technologies and new methods are developed and implemented to utilize resources in more optimized way. Sustainable food supply is essential globally for the world, however it has to be managed and achieved on local levels. We present the greenhouse production market restructuring with new players. What kind of difficulties arise in the open field vegetable production and what benefits can be realized by the customers and producers from the covered greenhouse technology in the continental and desert climate? What are the technical boundary conditions to establish and operate greenhouse production in different regions and what are the benefits realized from local food production? As an example, we analyse Qatar's energetics, climate conditions and food resources, Qatar's food supply process and its barriers. We will show how the sustainability and food safety appear in Qatar's National Strategy Plan.

Keywords: sustainability, food safety, greenhouse production, Qatar

\section{Introduction}

The world's agriculture and food industry will have to face huge challenges in the following decades. Today, 3 billion people rely on food which is produced elsewhere and transported to the cities, and it will grow to 7 billion by 2050, according to the projection of FAO (FAOSTAT, 2013). To meet the increasing demand of the people, the agricultural production must be increased by $60 \%$ from its $2005-2007$ levels (FAO, 2013). Apart from the increasing population, its consumption pattern also changes due to the higher income and health concerns (Figure 1). Higher consumption per capita increases especially in the emerging regions like Asia, Northern Africa and Latin America.

The present agricultural technology with the limited natural resources (land, water, fossils) together with the increasing demand for bioenergy can lead to the food shortage. The greatest challenge is in increasing the agricultural production to such high level is to carry it out in a sustainable way in order to secure food safety for the longer term. Therefore countries need to shift to more sustainable food systems to enable sustainable development aiming to lower the long term vulnerability of economic, social and ecological systems (Mubarak, et al, 2014).

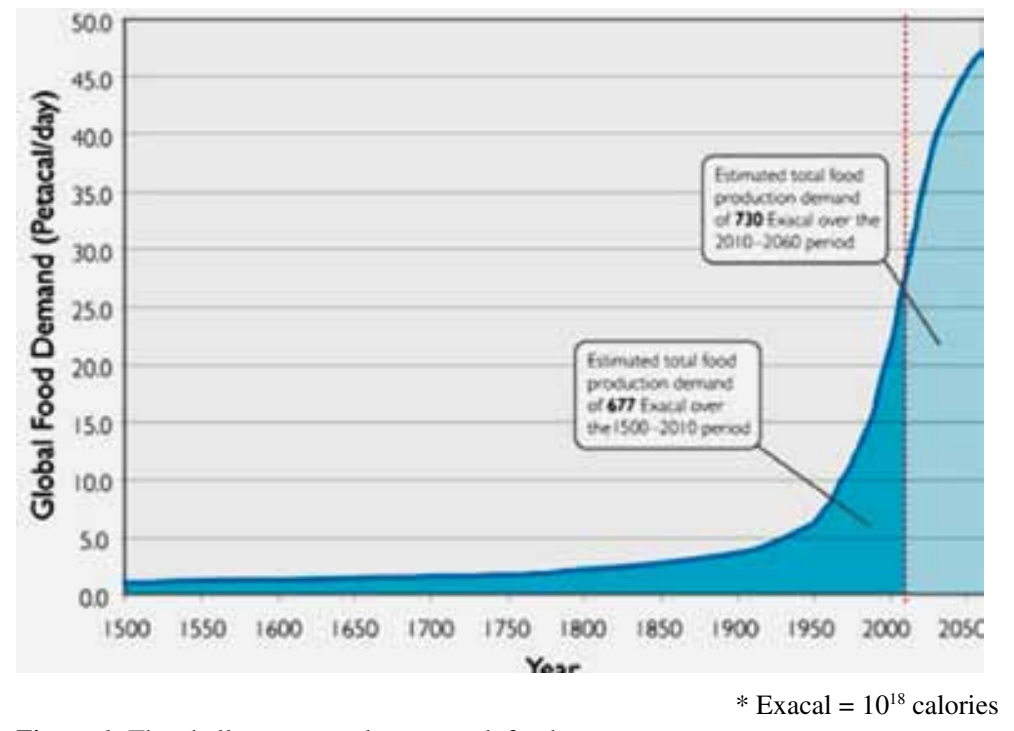

Figure 1: The challenge to produce enough food will be greater over the next 50 years then in all human history (source: Cribb, 2011) 


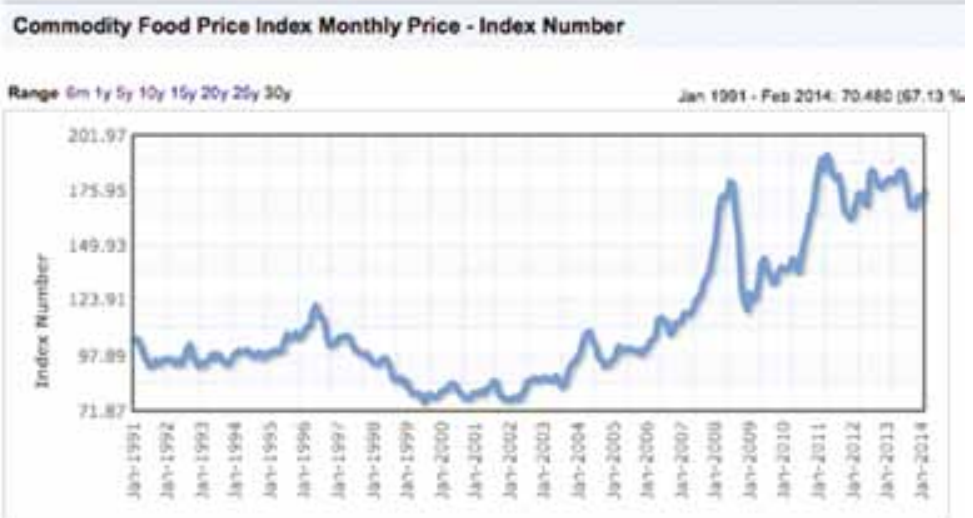

Figure 2: Past trend of world commodity food prices source: $\mathrm{FAO}, 2013$

The vulnerability of the poor countries high, because they have less power and fewer means to act, and also because they are mostly located in marginal production areas, where they are more exposed to the impact of climate changes. (FAO, 2013)

However, not only the poor and undeveloped countries can be suffer from the lack of food safety, even those who have well developed economy have to face high risk, if they don't possess the appropriate resources for food production, like Qatar for example.

Urbanization with the megacities brings in new risks to food safety as well, since food safety rely on the stable logistics of the food products. The more distance they have to deliver food to the consumers in the city the greater problems they face when problems arise in the logistical change, just like in Australia in Brisbane during 2010 December, when all the supermarkets were emptied in 2 days, because the transportation was cut off by the flood (Australian Government, 2012). The changing of food prices is the other factor which makes the low income population more vulnerable.

The food prices have started to increase in 2008 as another result of the global crises. According to most of the agro-economic models, a tendentially increasing price level is projected for the next decades.

In the less developed countries, the consumers' price elasticity demand is high, which will result a higher fruit and vegetable consumption level compared to the animal products (NL EVD International, 2011).

In the high income countries, the food consumption pattern is changing because of health concern, which brings also a higher need for vegetables. The higher demand for fruits and vegetables leads to higher intensity in research and development activities in the agricultural production for increased productivity and for the producers gaining market advantages.

The required higher level of agricultural production will generate increasing environmental risks. The potential of the agricultural production is limited, because the required major resources as water, land, nutrients, energy are not infinite and in addition, the geographical distribution of the resources is uneven.

In the below graph, we can see the richest and the poorest counties of the World, in terms of quantity of arable lands per capita (Figure 3).
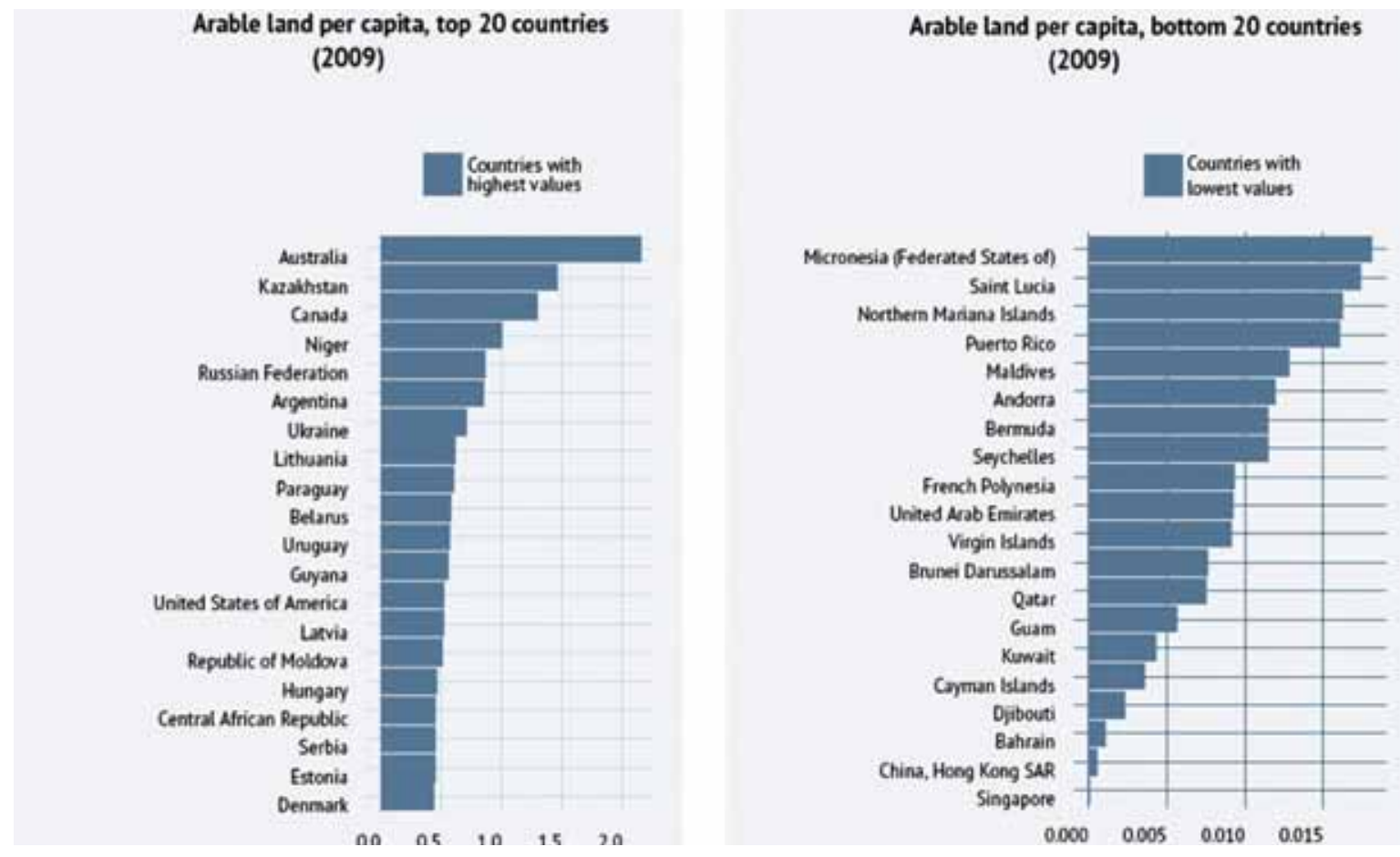

Figure 3. Demonstration of uneven geographical distribution of arable land source: FAO, 2013 
Today, the natural resources are used very intensively by the agriculture. 70 percent of the abstracted freshwater is used for irrigation and only 30 percent used by industrial and household purposes. 30 percent of the total land area of the Earth is used for agricultural production. This large-scale utilization of the natural resources means larger environmental threat. These major resources needed to secure our food supply: water, land, nutrients, energy, technology, skills, finance and stable climates (Australian Government, 2011)

From the required essentials of the production, the following resources are going to reach their maximum peak volume of their utilization in the near future.

- water

- land, concerning degradation, urbanization, population and infrastructure grow

- fossil energy

- artificial fertilizers' row materials (like phosphor and potash) (Rijsberman, 2012)

The greenhouse technologies open a new perspective and possibility to overcome the scarcity of the essential resources of the agricultural growing. In different climatic and terrain conditions, the greenhouse technologies can supply appropriate conditions for the vegetable and fruit growing, with enabling stable climate, soilless production, water saving irrigation, pest control, thus realizing stable and high quality yield .

Main drivers behind greenhouse production:

- benefits of the local production: short supply change lowering transport costs, longer lifetime of product from harvest to consuming, because it can be harvested just in time when the demand arises

- less costs due to lower waste

- stable quality needed by the consumers and distributors

- higher demand for environmental friendly products and organic growing

- emotionally linked consumers to local produced vegetables

- food safety

- possibility for soilless production.

\section{Materials and methods}

The results are presented in this paper are based on related international literature, company reports, personal interviews with experts, and the authors' own professional experience.

\section{Importance of greenhouse production in Europe and other parts of the world}

Although Europe is well supplied with the necessary resources for agricultural production, even the European Union has to faces serious challenges in the future, as:

- climate change

- increasing competition for water and arable land resources
- rising costs of inputs (fertilizes, fossil energy, etc.)

- changing of consumer diets because of health concerns and ageing population

- competition for export markets

Greenhouse technology production traditionally presents in Europe and has already reached very high technology level. The European production is characterised by a climate conditions associated to four climate regions, which allows for diversity in technologies and practices used for greenhouse vegetable production. Some countries of Europe are the leaders in the world greenhouse technology developments and obtain a large market share, for example the Netherlands or Italy. Due to the increasing demand for higher and stable quality for fruits and vegetables during the whole year, EU is the main export market destination of the world. That is one of the main reasons, why $20 \%$ of the total greenhouse surface area belongs to Europe according in to FAO in 2009 (FAO, 2013).

Apparently, some of the non-European producers like Morocco, Egypt or Israel are able to deliver their high and guaranteed quality products to the Western markets and compete the European price level thanks to their continues production development and lower labour costs (Carbgrowth, 2011).

Apart from the existing and experienced greenhouse horticultural players in the developed and less developed part of the world, due to the increasing demands and future risks, new - traditionally non-agricultural countries with marginal lands will also enter the greenhouse production thus taking non arable lands into food production.

We can find countries among these, with high per capita GDP and high dependency of food import.

In the literature, the sustainability issues are well analysed and presented about those countries on one hand, which are energy dependent with intensive agricultural production - focusing on energetics and food supply, or on the other hand about countries suffering from hunger and poverty focusing on food production. The sustainability issues have not been widely discussed related to those economies, where there is no fossil energy dependency from the consumer side, however they take serious steps for preserving their wellbeing for the future generations because of their vulnerability from the lack of food safety and their economic dependence from the fossil exports.

The cutting edge soilless food production technologies bring the possibility for sustainable, organic local food production even for regions, where the boundary conditions have not been given earlier for establishing greenhouse production in lack of natural soil and other necessary natural resources.

The large-scale soilless cultivation was the beginning of 1973. Five hectares was only in the Netherland in 1975 and was about 5-6 thousand hectares, twenty years later. In the last 25-30 years there has been increasing interest in the use of soilless or hydroponic techniques for producing greenhouse vegetable crops. Unfortunately, exact statistics are lacking from the soilless greenhouse area. There are three 
main types of soilless cultures: aggregateponics, hydroponics and aeroponics.

Some of the reasons why soilless growing is being adapted around the world for food production are the following:

\section{Advantages and disadvantages of soilless culture}

\section{Advantages}

- Obviously no soil is needed.

- Completely controlled production.

- Stable and high yields.

- Easier to protect against diseases and pests.

- No nutrition pollution is released into the environment because of the controlled system.

- Low water consumption.

- No herbicide treatments.

- No need for soil sterilization.

- Grow on poor soils.

- Fertigation and water supply are much easier.

- Less labour requirement.

\section{Disadvantages}

- Without soil as a buffer.

- High investment and energy costs.

- Possibly, the absence of suitable varieties.

In the following, we introduce and show through Qatar's example that an oil exporter country with marginal arable lands, what kind of characteristics and parameters has and what plans and actions has been made towards food safety and sustainability. We find Qatar a good example also for showing, that sustainability issues are always come to front, when the vulnerability appears on the horizon.

\section{Qatar's natural resources and economy}

In Qatar the land which can be used for agriculture measured at $5.61 \%$ of the total land according to the World Bank. Qatar is a rocky desert area with some oases formed by 850 separate depressions. In Qatar arable land defines land under temporary crops, temporary meadows, land under market or kitchen and land temporary fallow. The lands are highly saline. The total cultivated area is 6322 ha, including 67 ha of greenhouses. The total area of arable land is 2651 ha, which includes 1190 ha of vegetable crops and 1461 ha of field crops. The area under permanent crops amounts to 3 412 ha and comprises 1478 ha of perennials and forage crops and 1934 ha of fruit trees (FAO, 2002).

Qatar's performance has been constantly growing in the last decade and planning to sustain the high performance is an ultimate goal for the State. But every country or state needs to consider that besides economic growth the environment must be preserved and protected.

In general, the Gulf countries are wasteful in consumption; hence changes will be done to put in place preventive measures to mitigate the negative environmental effects of pollution resulting from the development activities. Preventive moves needs to be done in order to sustain the natural life. The Qatar National Vision 2030 sets initiations to perform actions towards sustainability even in environmental developments. The State of Qatar considers environmental issues as key drivers in achieving the national goals. Qatar is in a unique position, given the financial resources and forward thinking leadership, to move ahead and be amongst the leading countries ready to take advantage of the next economic revolution: the green revolution.

The most important topics affected environmental developments are: water sector, (water resource development, water security, water loss control and water management, and water quality standards), marine environment, climate change, and waste management. Marine water with advanced technology can be transformed potable water. The high intensity of solar power is available to transform into electricity, and the very frequent powerful winds are also possible to create it, therefore the variety of actions are wide in order to achieve the so called green revolution. Creating Qatar water and food secure through sustainable technologies is key point in sustainable development. In this field establishing leading edge food production systems as exemplar for agriculture in dry lands. One of the main objectives of Qatar is to become the food hub of the Gulf region due to its geological and economic status. Besides these for coming trends the green technologies are emphasized through all the national strategy plans.

The food production in domestic soil is very hard and challengeable job. The number of the decline of active farms since 2008 , more precisely $-30 \%$. The food dependency is very high, $90 \%$ of all food consumed in Qatar is imported (QNFSP, 2013).

Qatar belongs to one of the most food-import-dependent counties in the world, and it is even expected rising further in the future. In Qatar the opportunities of food choices were always being limited due to the dry lands. The main consumption were rice and sea foods due to the Persian and Indian migration. The high food-import-dependency can be addressed to both demand and supply-side factors. In the demand side there has been a lot change recently in the habit of food consumptions due to the high number of expatriates who insist on their own food. The Westernized meals have also become popular on the supply side even among local people. Fast-food restaurants have found way into the local market, therefore the production of own food is not a necessity anymore from the consumers' point of view.

\section{Food security issues in Qatar's national strategy}

The mission of the Qatar National Food Security Plan (QNFSP) is to manage the food security by setting goals and giving directions for the government and private sectors. The main tasks what the QNFSP should accomplish:

- Develop policies, plans and capacities that enable the nation's food system operationally 
- Monitor, assess and improve the performance of key parts of the nation's food system

- Provide outstanding/leading/ expertise that contributes to a knowledge economy in Qatar and provides services that contribute to global progress on food and water security

- Promote and support opportunities for the private sector

Concerning the expertise in Qatar and the global practice inside the framework of Qatar's National Vision 2030, the QNFSP (Qatar National Food Security Plan) was established to step towards sustainable food safety. The plan lays down a 10 year roadmap with actions for improving the national food system. The plan outlines 3 key principles:

- Improving the flexibility of the State of Qatar

- supporting environmental friendly and economically and socially sustainable developments

- strengthening and motivating the private sector's involvement into the economic growth

These key initiatives include:

- better technologies and practises have to be adapted for increasing efficiency and sustainability, and by transitioning to the high efficiency production farms will be able to produce $40 \%$ of the total food volume of the nation on the same amount of land with onethird less water, then it is required today

- strategic water reserves must be established

- boosting strategic food reserves

- diversifying trading and investment activities, improving and widening domestic market

- international cooperation and collaboration for food safety

At present time, the government of Qatar and the stakeholders are working to initiate the detailing and implementation of the QNFSP to form the plan into actions and realization.

\section{Sustainable development realization}

The strong need for utilization of non-arable lands has helped to be bringing in innovation and develop technologies which can make it possible greenhouse production even in the desert.

To be able to grow, stable, precisely controlled optimal condition has to be created for the plants during the year. In Europe, the greenhouse must be heated in the colder seasons or in the cold nights and carbon-dioxide must be applied for the plants. In the desert climate, both heating and cooling are needed for creating the optimal stable temperatures. Apart from the temperature, the most significant problem is the dryness. Irrigation is a must, but finding enough water in the desert is more difficult, then in the continental climate.

It shows the great development, that there are already green spots in the desert - these new areas have not been considered as arable lands in the past, but now due to the irrigation systems, these open fields produce agricultural products in the middle of the desert.

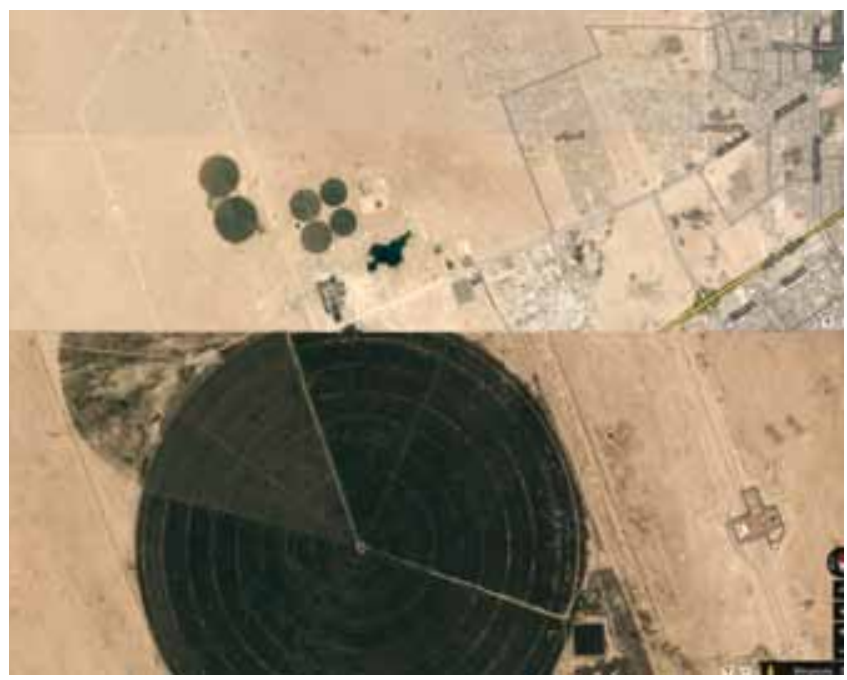

Figure 4. Green circles in the desert of Qatar source: google maps, 2014

These irrigation systems can provide enough freshwater from the pivot and also humidify the cultivation area. However, the temperature cannot be effectively controlled with this technology, thus allowing only a very limited portfolio for growing.

Apart from the open field irrigation technology, already a cutting edge technology has been developed for low operation cost, cooled and heated, covered, desalination greenhouses in the deserts. This technology produces freshwater for the irrigation from the saltwater.

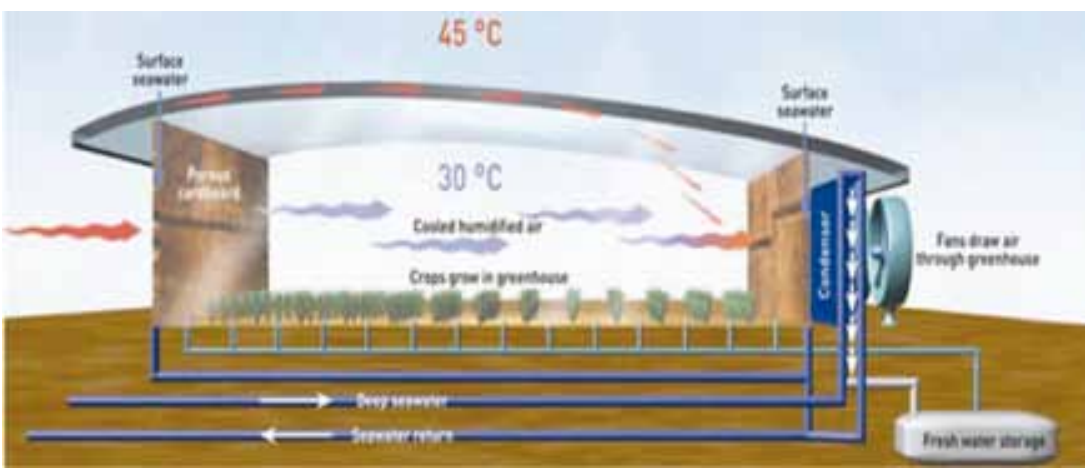

Figure 5.Illustration of a seawater greenhouse desalination facility source: Seawater Greenhouse Limited, 2010

A pilot project has been already realized in the desert of Qatar - for growing cucumbers using solar energy for heating and cooling and distilled salt water from the sea for irrigation.

A concentrated solar power plant (CSP) which is producing electricity from the steam generated from the salt water and solar energy - is combined with the greenhouse. The waste heat is used for heating the glasshouse and for regenerating the desiccant used for dehumidifying the air. 


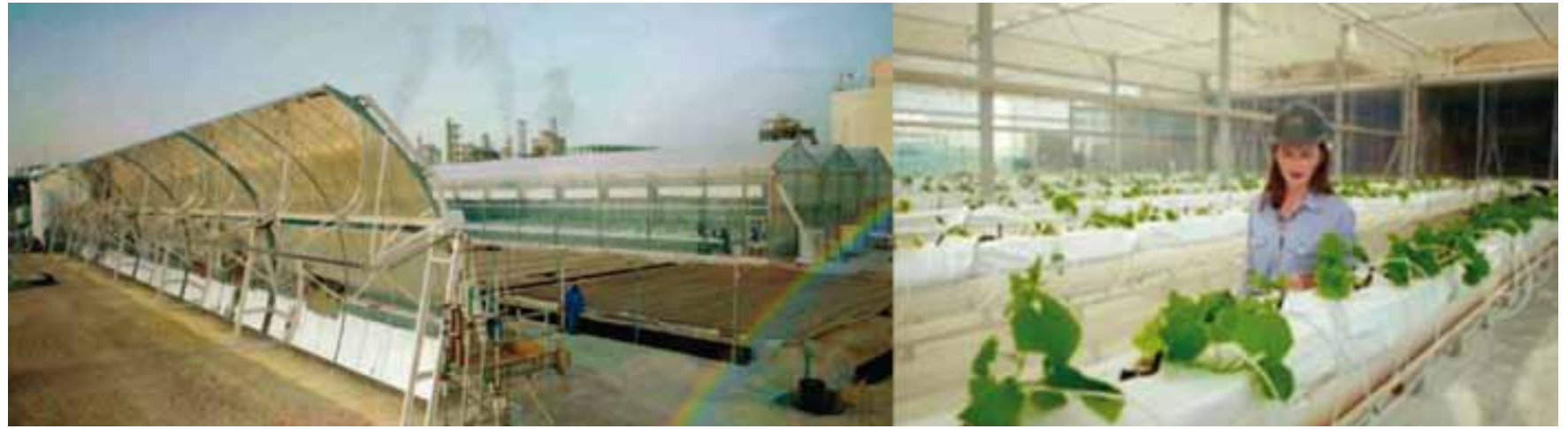

Figure 6: Cucumber forcing in the desert in the Sahara Desert Project source: Prophet, 2012

This combination brought alive a profitable system, which will probably mean a kick start of other similar projects.

Although significant part of the world has aimed different goals in the sustainable development, the expected goals have not yet been realized for many reasons. In order to achieve such grandiose strategic goals, the contribution and cooperation of the different players of the national economies are needed.

\section{Motivation of the players towards sustainability:}

- private sector: environment protection, caring for the upcoming generations

- business sector: business opportunity - if there is profit, companies will support

- public sector: long term thinking, safety

\section{How they can help sustainability:}

- private sector: select what products to buy, not only the cost should decide

- business sector: social responsibility over profit targets

- public sector: taxation, subsidy programs, education

When we talk about greenhouse production and sustainability in the agricultural growing, we should examine, what is needed to realize a sustainable development in the horticultural sector. The realization of the sustainable change can only take place, when all these preconditions are fulfilled:

- new technologies need to be developed and adapted

- outside pressure and force to motivate the change

- need the willingness for the change from both private and public sector

- need to be able to finance the development process

Examining our example, Qatar's financial background and the willingness for sustainability both from private and public sector, together with the available technology level from the market, we can expect that covered greenhouses will grow in the desert soon and significant local production will be realized.

\section{Conclusion}

Every country is vulnerable at food production and supply but from different perspectives and at different levels. Well developed economies have much more power to drive and invest into their future and safety, but countries with poor underdeveloped economies have to rely only on the help of other nations. As the problems arise of the overpopulation, the development and technology levels also increases at the same time. The question will be whether the technology development and the present actions of the nations can overcome the upcoming situation, when 9 billion people will ask for food or not. There are many promising achievements and movement already towards sustainability, but at present time they are surely not enough yet to avoid the future threat of lack of food.

\section{Acknowledgement}

The project was partly supported by ,az Emberi Erőforrások Minisztériuma által biztosított Kutató Kari Kiválósági Támogatás - Research Centre of Excellence 8526-5/2014/TUDPOL".

\section{References}

Australian Government, Dep. of Agriculture, Fishery and Forestry (2012): Resilience in the Australian food supply chain, http://www.tisn.gov.au/Documents/Resilience\%20in\%20the\%20 Australian\%20food\%20supply\%20chain \%20-\%20PDF\%20 copy\%20for\%20web.PDF. Website visited on August 10, 2014.

AQUASTAT, FAO (2002) : http://www.fao.org/nr/water/aquastat/ countries_regions/QAT/index.stm (DAWR, 2002). Website visited on August 10, 2014.

CARBGROWTH (2011): Maximisation of greenhouse horticulture production with low quality irrigation waters, http://en.wikioffuture. org/Maximisation_of_greenhouse_horticulture_production_with_ low_quality_irrigation_waters. Website visited on June 20, 2014.

CSIRO (2012): Sustainable Agriculture: Feeding the World presentation by Dr Megan Clark http://www.csiro.au/Portals/ Multimedia/On-the-record/Sustainable-Agriculture-Feeding-theWorld.aspx. Website visited on May 15, 2014. 
FAOSTAT (2013): FAO Statistical Yearbook, World food and agriculture, 2013 Food and Agriculture Organization of the United Nations, Rome

FAO (2014): Climate change's potential impact must figure in food production efforts http://www.fao.org/news/story/en/item/224958/ icode/. Website visited on August 10, 2014.

FAO (2013): Good Agricultural Practices for greenhouse vegetable crops Principles for Mediterranean climate areas, Rome http:// www.fao.org/docrep/018/i3284e/i3284e.pdf

Cribb, J. (2011): The Coming Famine, Risks and solutions for the food challenge of the 21 st century http://www.holysee.embassy. gov.au/files/hyse/Global\%20Food\%20Security\%20Oct11.PDF. Website visited on June 20, 2014.

Mubarak N. Y MAl-Ali, Gonda Gy. \& Fekete-Farkas M. (2014): Appearence of different dimensions of sustainable development, in national development strategies in. „Changing, Adapting Agriculture and Countryside". Congress held: Gyöngyös, Károly Róbert Főiskola,Hungary, on 2014.03.27-2014.03.28. 2014. pp. 1157-1165.

PROPHET (2012): Qatar's Sahara Forest Project Grows Its First Cucumbers from Saltwater - See more at: http://www. greenprophet.com/2012/12/qatars-sahara-desert-forest-projectgrows-cucumbers-from-saltwater/\#sthash.fIsp1Ifd. Website visited on May 15, 2014
Qatar National Food Security Programme (QNFSP, 2008):http:// www.qnfsp.gov.qa. http://www.qnfsp.gov.qa

Giles, P. (2012): Solar and seawater turn desert into a greenhousehttp://reneweconomy.com.au/2012/solar-and-seawaterturn-desert-into-a-greenhouse-28833, Website visited on June 20, 2014

Rijsberman, F. (2012): The scramble for natural resources: How can science help? http://purl.umn.edu/152416. Website visited on August 10, 2014

Sahara forest project (2013): Overview of Qatar pilot plans http:// saharaforestproject.com/projects/qatar.html. Website visited on August 10, 2014

Sahara forest project (2013): Qatar Pilot results exceed expectations http://saharaforestproject.com/news/news-stories/qatarpilot-results-exceed-expectations.html. Website visited on August 10,2014

Seawater Greenhouse Limited (2010): http://www.seawatergreen house. com/projects.html. Website visited on August 10, 2014

The Ministry of Economic Affairs, Agriculture and Innovation, NL EVD International (2011): Market Special: Greenhouse Farming in Germany http://duitsland. nlambassade.org/binaries/content/assets/postenweb/d/duitsland/ ambassade-berlijn/zaken-doen/20110507-marktverkenninggreenhouse-farming-germany.pdf. Website visited on May 10, 2014 